\title{
Effects of Abandoned Urban Infrastructure on Environmental Development in Ogun State
}

\begin{abstract}
The well-being of any nation is based on its readily available and functional infrastructure. The abandonment of urban infrastructure does become a threat and causes an environmental nuisance, slowing down development. The study assesses the impact of abandoned urban infrastructure on the environmental development of Ogun State. It examines the effects of abandonment on the environment and identifies the various causes and types of abandoned urban infrastructure in the state. Questionnaires and interviews were used to gather data from estate surveyors, valuers, and end users of urban infrastructure. The data was analyzed using a descriptive analysis and the Relative Importance Index (RII). The effects of abandoned urban infrastructure on environmental development were determined to be environmental degradation, a decrease in business activities, and an increase in health issues. The study recommends that infrastructural projects should be done in bits to avoid abandonment, on-going construction should always be kept clean to avoid negatives uses, good health care and environmental cleaning up should be done for the people, and the use of turnkey projects as well as the globally established PPP model of infrastructure delivery.
\end{abstract}

Keywords: abandonment, abandoned urban infrastructure, environmental development

* University of Lagos, Department of Estate Management, Lagos, Nigeria

** Moshood Abiola Polytechnic, Department of Estate Management and Valuation, Abeokuta, Nigeria; Covenant University, Department of Estate Management, Ota, Nigeria (corresponding author: ibisola.abayomi@mapoly.edu.ng) 


\section{Background to the Study}

The well-being of any nation lies on its functional and a readily available infrastructure. Infrastructural facilities play a key role in every nation and enhances the built environment. According to Nubi [1], infrastructure can be defined as the aggregate of all facilities that allow a society to function effectively, believing it as a wide range of economic and social activities crucial to creating and enabling an environment for economic growth and an enhanced quality of life.

The impact of abandoned urban infrastructure in Nigeria on our environmental sustenance is enormous due to the continuous abandonment of urban infrastructure in Nigeria(which has become very worrisome); thus, the need to pay urgent attention to the causes of this abandonment has become very germane. Abbas [2] opined that more than N5 trillion in government projects were abandoned across Nigeria, expressing "deep worry" over the situation considering the fact that the country was incurring huge losses due to the abandonment.

Odutola and Adeniran [3] pointed out that the massive infrastructural deficit is standing at about $\$ 2$ trillion according to development agencies, yet over N3 trillion worth of infrastructures projects have been found abandoned and unaccounted for by the sitting government in no fewer than ten states of the federation since 2012 . He further mentioned that the budget office of the federation, the state helmsmen caught in the web of the uncompleted or abandoned projects includes some immediate past and current governors of Ogun, Osun, Oyo, Ekiti, Rivers, Kwara, Kano, and Anambra States. This is a country where we are agitating for sustainable urban development, yet the money allocated for projects is not spent wisely, contractors do not chosenwisely, and supervision is lacking or missing entirely; the end result is uncompleted and abandoned projects.

According to Atilola [4], abandonment of infrastructures has a tremendous effect on the physical environment and poses a serious threat to the sustainability of the environment, attracting the most hopeless of any city's destitute population.

Ogun State has experienced a series of abandoned infrastructure such as road construction, housing, schools, hostels, and water projects (to mention but a few). This no doubt has generated some concerns, as the government has abandoned several existing projects without completion, and started some new projects, having less concern about the hardship caused due to some properties already demolished. Roads and drainages constructed halfway cause serious mess to the environment and thereby slow down business activities in such neighborhoods.

Abandoned urban infrastructure mostly create negative impacts on the society and make the environment unhealthy and unsafe. Efforts must be put in place to avoid these trends of the abandonment of urban infrastructures and completion of existing abandoned projects in order to breach the gap of the infrastructural deficit in Ogun State and Nigeria overall. Therefore, this study assesses the impact of aban- 
doned urban infrastructure on the environmental development of Ogun by identifying the causes and types of abandoned infrastructures and examines the effect of abandoned infrastructure on environmental development.

\section{Literature Review}

\subsection{Meaning and Causes of Abandoned Urban Infrastructures}

The Longman Dictionary [5] defines abandonment as the action of suspending activities on something totally with no definite intention of when to restart. Thus, when actions of on-going projects are postponed without any confirmed time of recommencement, the projects are said to be abandoned. Having understood the general meaning of "abandonment," project abandonment is the unexpected postponement of work progress particularly at the implementation stage such as the inability to complete a contract after the completion period has elapsed. Abandonment and unsuccessful projects that are more widespread in the government sector litters every array of the nation's environment such as housing estates, government quarters, university hostels, public schools, roads, and bridges (to mention a few). The occurrence cuts across various financial sectors, including the building, manufacturing/engineering, and service sectors [6]. Abandoned projects are projects that are vacant, vandalized, boarded-up, dilapidated, or unmaintained. "Abandonment" can also be defined as when the client refuses to provide maintenance and working services to a building, the failure of an owner's authoritative right to a building, or the destruction of a building [7] noted that abandoned infrastructural projects can be described as projects that started on an earlier date but where the construction work has stopped for one reason or another. These are not limited to buildings alone - roads, industrial structures, bridges, factories, dams, electricity, communication projects, and so on are equally on the list. Dada [8] sees an abandoned building project as a project in which the construction work is incomplete and suspended.

Various researchers have identified and shared their views on the associated causes of infrastructural project abandonment in Nigeria. Among these are the research conducted by Wahab [9] and Opawole et al. [10], which show that infrastructural development revealed that Nigeria was losing a whooping sum of about \$265 million annually before 1999 via different types of illegal procedures in the award of contracts by government officials, while according to [10], only $45.3 \%$ of the road projects covered by public budgets have been implemented in Nigeria. In line with this study, Olufidipe [11] identified a significant number of projects contained in the annual budgets of the government at all levels in Nigeria as either partly implemented or not implemented at all, thus resulting in wide divergence and the persistent disparity between the actual and projected budget figures.

From a different view, EIUS [12]reported and listed the leading obstacles to urban infrastructure and services, among which are a lack of adequate suppliers, poor governmental effectiveness, a lack of political will or sense of urgency, a lack of public 
funds, a lack of skills, knowledge, or training of the officials in this area, a lack of an effective procurement process, corruption or misuse of funds earmarked for infrastructure and services, a lack of an appropriate regulatory framework, and a focus on new investments over the necessary maintenance of the ongoing projects. Another view on the causes was discussed in Yeo [13], who cited that a hostile company culture, political pressure, an improper reporting structure, external influences, vested interests, and an inappropriate level of management commitment are the organizational and managerial causes of urban infrastructural project abandonment. In the survey of Dada [8], the importation of materials and equipment is a very important variable among the construction technology variables that contribute to the abandonment of building projects in case there is no supply of such materials and equipment from the neighboring countries; also, a lack of funds contributes greatly and immensely as one of the factors affecting the completion of infrastructural projects as a result of the non-provision of funds by clients. Tomori [14] argued that a lack of funds alone as exclaimed by many authors is not a root cause of poor infrastructure and services - it is a symptom of more fundamental problems. These include instability, lack of confidence, distorted economic policies, and difficulties of governance.

Akanni, Oke, and Akpomiemie [15] highlighted other factors that encompass the abandonment of infrastructural projects, among which are political, legal, institutional, cultural, sociological, and technological resources along with economic, financial, and physical infrastructure. In their studies, they were able to consider some factors within the environment that pose greater challenges to projects, believing that these factors ought to form the center for the management of a project's environment. Similarly, other factors discussed by Atilola [4] include customs and traditions, technology, secret owners, legal, political and physical factors as responsible for the causes of an abandoned project. Citing Aluko [16], Ayodele and Alabi [17] argued that the bankruptcy of the contractor, variations of a project's scope, and incompetent project managers are other causes of project abandonment.

\subsection{Problems, Challenges, and Effects of Abandoned Urban Infrastructures on Environmental Development}

No doubt, abandoned projects place numerous challenges and problems on the environment and economic development at large. Olalusi and Otunola [7] stated that abandoned infrastructural projects affect the entire environment by defacing the aesthetics, hindering accessibility, and creating social problems as well as other health hazards to the entire populace. In their study, they opined that most construction projects that would have impacted development in Nigeria littered the nooks and crannies of the entire country. Abandoned housing attracts the most hopeless of any city's destitute population. Abandoned buildings have a negative impact on the social as well as the purely economic aspects of well-being [18]. 
According to Dosumu and Akinsiku [19], the effects of project abandonment in Nigeria cannot be underestimated, as it has consequences on the stakeholders (clients, consultants, contractors, and users) and the nation as a whole. This then suggests that, for there to be a sustainable environment, abandoned properties must be done away with in our neighborhoods. Similarly, Atilola [4] acknowledged that the abandonment of a project has a tremendous effect on the physical environment and poses a serious threat to the sustainability of the environment. Carrero, Malvarez, Navas, and Tejada [20] described the impacts of an abandoned project as both socio-economic and environmental. On the other side, Henachor [21] opines that project abandonment has its effect on individuals, the community, and the government. Brachman [22] puts the problem and effect of vacant and abandoned infrastructure as a problem with ramifications for the quality of our public and private lives because abandonment can lead to other detrimental social and fiscal impacts: depressed property values of the surrounding properties, increased criminal activity, and health and safety concerns due to the environmental hazards and additional disinvestment.

\section{Methodology}

The population for this study comprises of the end users of urban infrastructures such as roads, drainage, bridges, schools, hostels, and housing; i.e., the National Union of Road Transport Workers (NURTW), residents of Idi-Aba and civil servants of the Kemta Housing Estate, and practicing estate surveyors and valuers involved in project development with cognate practical experience each with a minimum of five years of experience in the field of practice. These are land economists who, by the nature of their jobs, representand act for various firms or clients whose investments are directly or indirectly affected by the abandonment of infrastructural projects. The study adopted both primary and secondary sources of data collection. The primary data used for this study was gathered through the use of questionnaire and interviews using random and purposive sampling techniques. Questionnaires were administered to the 18 estate surveyors and valuers in Abeokuta out of which $16(89 \%)$ were retrieved. Additionally focal group interviews were conducted for the various end users. The data was analyzed using a descriptive analysis. The Relative Importance Index (RII) was used to express the statistical results in achieving the objectives of the study. Therefore, all of the analyzed data was duly presented, discussed, and interpreted in other ways to draw meaningful conclusions.

\section{Data Analysis, Findings, and Discussion}

Table 1 assessed and ranked the various types of abandoned urban infrastructure in Ogun State according to their level of agreement on the abandonment of the identified infrastructures. Having an RII of (0.88), road construction was ranked 
first, followed by school/hostel building (RII - 0.8; second), construction of bridges (RII - 0.79; third), Drainage (RII - 0.76; fourth), and housing (RII - 0.70; fifth) among the urban infrastructural projects abandoned in Ogun State.

This indicates that there is abandoned urban infrastructure in Ogun State, with road and school building having the highest occurrence of abandonment. These types of projects littered every part of Ogun State (some of which are provided in the plates in the appendix).

Table 1. Assessment of abandoned urban infrastructural projects in Ogun State

\begin{tabular}{|c|c|c|c|c|c|c|c|c|c|}
\hline $\begin{array}{l}\text { Type of } \\
\text { project }\end{array}$ & SA & A & U & D & SD & Total & Mean & RII & Rank \\
\hline $\begin{array}{l}\text { Road } \\
\text { construction }\end{array}$ & $\begin{array}{c}6 \\
30\end{array}$ & $\begin{array}{l}10 \\
40\end{array}$ & $\begin{array}{l}0 \\
0\end{array}$ & $\begin{array}{l}0 \\
0\end{array}$ & $\begin{array}{l}0 \\
0\end{array}$ & $\begin{array}{l}16 \\
70\end{array}$ & 4.3750 & 0.88 & $1^{\text {st }}$ \\
\hline $\begin{array}{l}\text { Bridge } \\
\text { construction }\end{array}$ & $\begin{array}{c}2 \\
10\end{array}$ & $\begin{array}{c}8 \\
40\end{array}$ & $\begin{array}{l}2 \\
6\end{array}$ & $\begin{array}{l}3 \\
6\end{array}$ & $\begin{array}{l}1 \\
1\end{array}$ & $\begin{array}{l}16 \\
63\end{array}$ & 3.9375 & 0.79 & $3^{\text {nd }}$ \\
\hline Drainage & $\begin{array}{c}5 \\
25\end{array}$ & $\begin{array}{c}7 \\
28\end{array}$ & $\begin{array}{l}1 \\
3\end{array}$ & $\begin{array}{l}2 \\
4\end{array}$ & $\begin{array}{l}1 \\
1\end{array}$ & $\begin{array}{l}16 \\
61\end{array}$ & 3.8125 & 0.76 & $4^{\text {th }}$ \\
\hline $\begin{array}{l}\text { Housing } \\
\text { estate }\end{array}$ & $\begin{array}{c}5 \\
25\end{array}$ & $\begin{array}{c}6 \\
24\end{array}$ & $\begin{array}{l}2 \\
6\end{array}$ & $\begin{array}{l}2 \\
4\end{array}$ & $\begin{array}{l}1 \\
1\end{array}$ & $\begin{array}{l}16 \\
56\end{array}$ & 3.5000 & 0.70 & $5^{\text {th }}$ \\
\hline $\begin{array}{l}\text { School/Hostel } \\
\text { building }\end{array}$ & $\begin{array}{c}7 \\
35\end{array}$ & $\begin{array}{c}7 \\
24\end{array}$ & $\begin{array}{l}1 \\
3\end{array}$ & $\begin{array}{l}1 \\
2\end{array}$ & $\begin{array}{l}0 \\
0\end{array}$ & $\begin{array}{l}16 \\
64\end{array}$ & 4.0000 & 0.8 & $2^{\text {nd }}$ \\
\hline
\end{tabular}

Source: own study, 2017.

Note: $\mathrm{SA}$ = strongly agreed; $\mathrm{A}$ = agreed; $\mathrm{U}$ = undecided; $\mathrm{D}$ = disagreed; $\mathrm{SD}$ = strongly disagreed.

Table 2 shows the assessment of the effects of abandoned urban infrastructure on the environment/neighborhood in Ogun State. The respondents ranked the decline of property condition first (with an RII of 0.88), disappointment of populace second (RII - 0.86), menace to the beauty of the environment and lowering of living standard were tied for third (RII - 0.81), health problems fourth (RII - 0.80), traffic congestion fifth (RII - 0.78), defacing the aesthetics of urban centers sixth (RII - 0.75), pollution of environment seventh (RII - 0.69), hideout for criminals eighth (RII - 0.66), structural failure (collapse of building) ninth (RII -0.63 ), and migration tenth (RII - 0.58) as the various effects of abandoned urban infrastructure on the environment/neighborhood in Ogun State. The decline in property condition was ranked higher because the respondents were estate surveyors and they clearly understand the effects of abandoned infrastructure on properties, followed by disappointment of the populace; this is obvious because many of the populace are really complaining and are disappointed about the abandoned projects in different parts of the state, as it is truly affecting their business, health, and daily activities. The response reveals that abandoned urban infrastructure has numerous effects on the environment/neighborhood in Ogun State. However, but declining in property condition, the disappointment of the 
populace, the menace to the beauty of the environment, and the lowering of the living standard and health problems are among the highest effects of abandoned urban infrastructure.

Table 2. Assessment of effects of abandoned urban infrastructures on environment/neighborhood in Ogun State

\begin{tabular}{|l|c|c|c|c|c|c|c|c|c||}
\hline \multicolumn{1}{|c|}{ Effects } & VH & H & M & L & VL & Total & Mean & RII & Rank \\
\hline \hline Disappointment of & 7 & 8 & 0 & 1 & 0 & 16 & & & \\
populace & 35 & 32 & & 2 & 0 & 69 & 4.3125 & 0.86 & $2^{\text {nd }}$ \\
\hline Lowering of living & 5 & 8 & 2 & 1 & 0 & 16 & & & \\
standard & 25 & 32 & 6 & 2 & 0 & 65 & 4.0625 & 0.81 & $3^{\text {rd }}$ \\
\hline Structural failure & 3 & 4 & 3 & 4 & 2 & 16 & & & \\
(collapse of building) & 15 & 16 & 9 & 8 & 2 & 50 & 3.1250 & 0.63 & $9^{\text {th }}$ \\
\hline Declining property & 6 & 10 & 0 & 0 & 0 & 16 & & & \\
condition & 30 & 40 & 0 & 0 & 0 & 70 & 4.3750 & 0.88 & $1^{\text {st }}$ \\
\hline Criminal hideout & 3 & 5 & 2 & 4 & 2 & 16 & & & \\
& 15 & 20 & 6 & 8 & 2 & 53 & 3.3125 & 0.66 & $8^{\text {th }}$ \\
\hline Menace to beauty of & 4 & 9 & 3 & 0 & 0 & 16 & & & \\
environment & 20 & 36 & 9 & 0 & 0 & 65 & 4.0625 & 0.81 & $3^{\text {rd }}$ \\
\hline Migration & 0 & 5 & 4 & 7 & 0 & 16 & & & \\
& 20 & 12 & 14 & 0 & 46 & 2.8750 & 0.58 & $10^{\text {th }}$ \\
\hline Pollution of & 2 & 7 & 4 & 2 & 1 & 16 & & & \\
environment & 10 & 28 & 12 & 4 & 1 & 55 & 3.4375 & 0.69 & $7^{\text {th }}$ \\
\hline Health problems & 4 & 9 & 2 & 1 & 0 & 16 & & & \\
& 20 & 36 & 6 & 2 & 0 & 64 & 4.0000 & 0.80 & $4^{\text {th }}$ \\
\hline Traffic congestion & 4 & 8 & 2 & 2 & 0 & 16 & & & \\
& 20 & 32 & 6 & 4 & 0 & 62 & 3.8750 & 0.78 & $5^{\text {th }}$ \\
\hline Defacing aesthetics & 2 & 10 & 2 & 2 & 0 & 16 & & & \\
of urban centers & 10 & 40 & 6 & 4 & 0 & 60 & 3.7500 & 0.75 & $6^{\text {th }}$ \\
\hline \hline
\end{tabular}

Source: own study, 2017.

Note: $\mathrm{VH}=$ very high; $\mathrm{H}=$ high; $\mathrm{M}=$ moderate; $\mathrm{L}=$ low; $\mathrm{VL}=$ very low.

\subsection{Results of the Interview} with National Union of Road Transport Workers (NURTW)/ Drivers at Mowe, Pasenke, Ogba-Ayo, and Lafenwa Motor Parks on Effect of Abandoned Infrastructural Projects on End Users

The focal group discussion and interview conducted revealed the following:

- It was anonymously accepted by the respondents that there is abandoned infrastructure within the state; among the identified abandoned infrastructure were roads, bridges, and schools as the ones known to them. 
- There are diverse opinions on how the abandoned urban infrastructure affects them individually. Many agreed that the abandoned urban infrastructure defaces and lowers the standard of living in their neighborhoods, are a menace to the environment, pollute the neighborhood/ environment, and cause health problems, while majority believe that abandoned urban infrastructure is an hindrance to their daily transportation business activities, as it creates traffic congestions, affects the number of times they go on a business trip per day, and also has an effect of their vehicles due to the bad roads that damage their cars/buses. The cost of maintenance and repairs goes very high, and the life spans of their vehicles are shortening.

\subsection{Results of Interview with the residents of Idi-Aba and Civil Servant within Housing Scheme on Effect of Abandoned Infrastructural Projects on End Users}

The focal group discussion and interview conducted revealed the following:

- The residents and students collectively agreed that there are abandonments of houses and hostel accommodation projects within the housing estate and institution, respectively.

- The residents of the Idi-Aba housing scheme further acknowledged that the abandoned houses within the estate and its neighborhood have negative effects on the well-being of the residents of the estate and people within the environment. They mentioned that the abandonments have created hideouts for criminal activities such as smoking Indian hemp, gambling, etc., and they believe that the abandoned houses and schools also disfigure the face of the housing due to the fact that the place is bushy and unkempt.

\section{Conclusion and Recommendations}

The occurrence of abandoned urban infrastructure in Ogun State and Nigeria as a whole continues to increase, and it is becoming very unbearable for urban dwellers; however, the need to check these trends of abandoned urban infrastructure calls for urgent attention

Ogun State is presently experiencing a good amount of abandoned infrastructure that has raised much concern and agitation from the general public. It is good to carry out a capital project, but the government should not bite more than it can chew. Why embark on multiple projects at a time knowing full well that the available funds would be sufficient to fund all of the projects at one time. However, considering the aforementioned concerns, the following recommendations were given: 
1. Urban infrastructural projects should be done bit by bit, especially road construction. Road construction should be done according to the finances available rather than demolishing property for a very long range and not be able to finish it for years; this puts the environment in a terrible condition and people into harsh conditions within that period.

2. There should be a diversification of the sources of funding to execute infrastructural projects rather than relying on the federal government allocation and/or bonds from foreign countries, because when such funds are denied, it affects the projects. Projects such as the Turnkey Projects and BOT model of infrastructure delivery should be adopted.

3. Private and public building still under construction or abandoned should always be kept clean to avoid being used for criminal hideouts.

4. Good health care and environmental clean-up should be done within the environment facing health-related issues due to the abandoned projects to enhance their standards of living.

\section{References}

[1] Nubi T.G.: Procuring, managing and financing urban infrastructure: towards an integrated approach. [in:] Omirin M.M., Olu Nubi T., Fawehinmi A. (eds.), Land management \& property tax reform in Nigeria: Proceedings of a National Workshop organized by the Department of Estate Management, University of Lagos, Akoka, Lagos, Nigeria, Department of Estate Management, University of Lagos, 2003, pp. 233-254.

[2] Abbas T.: Over N5tr projects abandoned across Nigeria - Reps. December 2016, [on-line:] http://www.vanguardngr.com/2016/12/n5tr-projectsabandoned-across-nigeria-reps/ [access: 08.08.2017].

[3] Odutola A., Adeniran Y.: 10 states abandon N3trn projects - investigation. January 2017, [on-line:] http://webcache.googleusercontent. com/search?q=cache:9Nev97ewTpkJ:www.thepointng.com/10-statesabandon-n3trn-projects-investigation $/+\& \mathrm{~cd}=1 \& \mathrm{hl}=\mathrm{pl} \& \mathrm{ct}=\mathrm{clnk} \& \mathrm{gl}=\mathrm{pl} \&$ client=firefox-b-ab [access: 20.01.2017].

[4] Atilola M.I.: Enforcement of lease term as a means of preventing abandonment of properties in public estate [a critical analysis submitted to the Council of the Nigerian Institution of Estate Surveyors and Valuers], 2009.

[5] Longman Dictionary of Contemporary English. Pearson Education Limited, 2005, [retrieved from:] Journal Emerging Trends Economics and Management Sciences (JETEMS), 2(2), pp. 142-145.

[6] Chinedu C.N., Fidelis I.E.: Building construction project management success as a critical issue in real estate development and investment. American Journal of Social and Management Sciences, vol. 2(1), 2011, pp. 56-75. 
[7] Olalusi O., Otunola A.: Abandonment of Building Projects in Nigeria A Review of Causes and solutions. [in:] International Conference on Chemical, Civil and Environment engineering (ICCEE' 2012) March 24-25, 2012 Dubai, pp. 253-255.

[8] Dada S.A.: An evaluation of the environmental factors that lead to abandonment of public building projects in the Federal Capital Territory, Abuja. Ahmadu Bello University, Department of Building Faculty of Environmental Design, Zaria2016 [M.Sc. thesis], [on-line:] http://kubanni.abu.edu.ng/jspui/bitstream/123456789/8840/1/AN\%20EVALUATION\%20OF\%20THE\%20ENVIRONMENTAL\%20FACTORS\%20THAT\%20LEAD\%20TO\%20ABANDONMENT\%20OF\%20PUBLIC\%20BUILDING\%20PROJECTS\%20IN\%20 THE\%20FEDERAL\%20CAPITAL\%20TERRITORY\%2C\%20ABUJA.pdf [access: 08.08. 2017].

[9] Wahab K.A.: Implementation of public procurement reforms in Nigeria. [presentation at:] Workshop World Bank Procurement Procedures, Nigeria Economic Summit Group, Ikoyi, Lagos, $28^{\text {th }}$ September 2000.

[10] Opawole A., Jagboro G.O., Babatunde S.O., Opawole M.O.: Critical factors in road infrastructure development in Osun state, south western Nigeria. International Journal of Development and Sustainability, vol. 2, no. 1, 2010, pp. 240-253. ISDS Article ID: IJDS12092802.

[11] Olufidipe O.: Government Budgeting in Nigeria: Principle, Policies, and Practices. Obafemi Awolowo University Press, Ile-Ife, Nigeria 2003.

[12] Economist Intelligence Unit Survey (EIUS): Urban infrastructure insights 2015 [a report written by the Economist Intelligence Unit EIU and sponsored by Fomento de Construcciones y Contratas FCC], 2015 [on-line:] http://www.fcc-group.eu/files/documents/group/urban\%20infrastructure\%20insights\%202015.pdf [access: 08.08.2017].

[13] Yeo K.T.: Critical failure factors in information system projects. International Journal of Project Management, vol. 20, 2002, pp. 241-246.

[14] Tomori M.A.: Housing and urban infrastructure development in Nigeria. 2014, [on-line:] http://macosconsultancy.com/Publication/HOUSING\%20AND \%20URBAN\%20INFRASTRUCTURE\%20DEVELOPMENT\%20IN\%20 NIGERIA.pdf [access: 08.08.2017].

[15] Akanni P.O., Oke A.E., Akpomiemie O.A.: Impact of environmental factors on building project performance in Delta State, Nigeria. HBRC Journal, vol. 11, issue 1, 2015, pp. 91-97. DOI: 10.1016/j.hbrcj.2014.02.010.

[16] Aluko O.: Impact of poverty on housing condition in Nigeria: A case study of Mushin Local Government Area of Lagos State. Journal of African Studies and Development, vol. 4 (3), 2012, pp. 81-89. DOI:10.5897/JASD11.047.

[17] Ayodele E.O., Alabi O.M.: Abandonment of construction projects in Nigeria: causes and effects. Journal of Emerging Trends in Economics and Management Sciences (JETEMS), vol. 2(2), 2013, pp. 142-145. 
[18] Setterfield M.: Abandoned buildings: models for legislative and enforcement reform. Research Project, 23, Trinity Center for Neighborhoods, Hartford 1997.

[19] Dosumu O.S., Akinsiku E.O.: Effects of project management on abandonment of building Projects in Lagos state, Nigeria. [in:] $9^{\text {th }}$ UNILAG Annual Research Conference and Fair. Volume 3, Department of Building, Faculty of Environmental Sciences, University of Lagos, Lagos 2014, pp. 126-134.

[20] Carrero R., Malvarez G., Navas F., Tejada M.: Negative impacts of abandoned urbanization projects in the Spanish coast and its regulation in the law. Journal of Coastal Research, special issue 56, 2009, pp. 1120-1124.

[21] Hanachor M.E.: Community Development Project Abandonment in Nigeria: causes and effects. Journal of Education and Practice, vol. 3 (6), 2012, pp. 33-36.

[22] Brachman L.: Vacant and abandoned property. Remedies for acquisition and redevelopment. Landline Article, vol. 17, no. 4, 2005, pp. 1-5.

\section{Wpływ zaniechania budowy i rozwoju infrastruktury miejskiej na rozwój środowiska w stanie Ogun}

Streszczenie Dobrostan każdego narodu opiera się na łatwo dostępnej i funkcjonalnej infrastrukturze. Zaniedbania w dziedzinie infrastruktury miejskiej stają się zagrożeniem i powodują uciążliwości środowiskowe spowalniające rozwój. W artykule oceniano wpływ zaniechania budowy i rozwoju infrastruktury miejskiej na rozwój środowiska w stanie Ogun. Zbadano wpływ powyższych działań na środowisko, ustalono przyczyny zaniechań w zakresie różnych typów infrastruktury miejskiej w Nigerii. Do zebrania danych od inspektorów i rzeczoznawców majątkowych oraz użytkowników końcowych infrastruktury miejskiej wykorzystano narzędzia: kwestionariusz ankietowy i wywiad. Dane poddano analizie opisowej i analizowano za pomocą względnego wskaźnika ważności. W wyniku badań ustalono, jaki wpływ na rozwój środowiska miało porzucenie infrastruktury miejskiej: degradacja środowiska, zmniejszenie działalności gospodarczej, występowanie problemów zdrowotnych. Autorzy zalecaja aby projekty infrastrukturalne były wykonywane w sposób pozwalający uniknąć porzucenia, a istniejące konstrukcje powinny być poddawane konserwacji.

Słowa

kluczowe: $\quad$ zaniechanie, opuszczona infrastruktura miejska, rozwój środowiska 